\title{
A Financial Analysis Approach on the Promotion of Peace through Economic Interdependence
}

\author{
Thomas Poufinas*, Victoria Pistikou \\ Department of Economics, Democritus University of Thrace, Komotini, Greece \\ Email: *tpoufinas@gmail.com
}

How to cite this paper: Poufinas, T. and Pistikou, V. (2018) A Financial Analysis Approach on the Promotion of Peace through Economic Interdependence. Theoretical Economics Letters, 8, 3611-3636. https://doi.org/10.4236/tel.2018.815222

Received: November 7, 2018

Accepted: December 11, 2018

Published: December 14, 2018

Copyright $\odot 2018$ by authors and Scientific Research Publishing Inc. This work is licensed under the Creative Commons Attribution International License (CC BY 4.0).

http://creativecommons.org/licenses/by/4.0/

\section{(c) (i) Open Access}

\begin{abstract}
The question of whether economic interdependence promotes peace is more than ever relevant once and again due to a series of conflicts around the globe. Two schools advocate the two opposite beliefs; these are Realism and Liberalism. The former supports that economic interdependence does not necessarily promote peace, whereas the latter trusts that it does. In our paper, we use a financial analysis-econometric approach to realize that there is evidence that supports that economic interdependence between two states in conflict does not promote peace since it has no significant impact on the configuration of the conflict. Consequently, it does not provide a significant enhancement in the levels of national security.
\end{abstract}

\section{Keywords}

Economic Interdependence, Relative Power, National Security Threat, Realism, Liberalism

\section{Introduction}

It has been long debated whether economic interdependence promotes peace or not. There are arguments in both directions represented primarily by two schools: Realism and Liberalism.

Realism interprets the political and economic behavior of states. Cooperation between states creates asymmetric gains for each partner, therefore states care about relative gains [1]. In addition, those who agree with the argument that today's economic interdependence has changed the environment and the nature of international politics, should be more skeptical, since groups and states have managed to increase their gains through economic growth and international 
cooperation. When the levels of economic interdependence start rising, states become more suspicious regarding the loss of their autonomy and the costs involved, as the result of interdependence. This is due to the fact that societies care more for their gains and they are not willing to sacrifice their welfare in favor of interdependence. The raising levels of economic interdependence make states more anxious about preserving their autonomy, their access to foreign markets and valuable raw materials as well as the cost that economic interdependence entails [2]. Last but not least, according to Realism, economic policies are supportive of security issues, since economy is a tool of foreign policy. As Mastanduno [3] mentions, the state's strategic principles are primarily based on three variables. The first is the structure of the International System, the second is the role of policy-makers and the third is the state's position in international economic competition.

Liberalism introduced "Idealism" [4] as a new perspective for understanding international politics. For Liberals, determinants such as individual liberty, interdependence, prosperity, democratic values, free trade, collective security as well as the power of public opinion are what promote peaceful relations among states. Although they agree with Realists that the international system is dominated by anarchy, that is to say by the absence of a power above all which would be able to control repressive mechanisms and maintain world order and peace, Liberals are more optimistic regarding peaceful cooperation among states. They argue that war can be avoided since there are other factors which increase people's prosperity and cooperation, such as domestic and international institutions and high levels of democratic values. In addition, Neo-Liberals also built on Cobden's beliefs about the peaceful impact of free trade on states and on Keohane's and Nye's [5] argument about interaction in several sectors. According to the latter, interests groups, transnational corporations and other actors should be taken into account because these non-state actors not only influence decision-making but also make states more interdependent, by raising the levels of collaboration as well as the costs of a potential withdrawal from these common fields. For example, the Bretton Woods system or NATO represent the institutionalized power of the USA. Also, Keohane's and Nye's complex interdependence [6] does not agree with Realists' distinction between high and low politics. On the contrary, they mention that there are many interactions among non-state actors which define international politics, and therefore military force is no more efficient as a tool of statecraft.

In this paper, we aim at validating the argument that economic interdependence between two states in conflict does not promote peace since it has no significant impact on the configuration of the conflict. Consequently, it does not provide a significant enhancement in the levels of national security. Moreover, we intend to show that the increasing economic interdependence between adversaries does not change the national interests of both sides. As a result, since the national interest is not affected by the level of economic interdependence between two rivals, the conflict will continue to exist. 
The theoretical perspective on which we count on is Realism. In International Political Economy, policy is considered to prevail above economics. Consequently, the latter serves the state's national interests. In addition, the state is the dominant actor in the international arena, without ignoring the impact of the non-state actors. However, the state is the most important actor since it is the only which guarantees human survival and gives the opportunity to non-state actors to develop their actions. In addition, anarchy is the main feature of an international system; therefore, conflict rather than cooperation defines the relations among states. In addition, states are suspicious to each other's motives; hence, relative gains are more important than absolute gains. The main objective of the states is survival. Therefore, they use their power either to maintain their security or to gain more power.

In our paper we use a financial analysis perspective as we consider a series of variables pertaining to the financials of the two countries to show that there is no clear evidence that economic interdependence promotes peace. To achieve that, we employ a series of econometric models.

\section{Background Discussion and Literature Review}

The academic discussion on whether trade and economy promote peace relies mainly on the theoretical aspect of Liberalism and Realism. Regarding the first, the main point is that there is a direct connection between trade and conflict, in other words, between economic factors and security issues. Most of the authors argue that not only does trade promote peace, but also that conflict decreases trade [7]. According to the Liberal Interdependence approach, the division of labor in the international economy is the main determinant, creating high levels of interdependence between states thereby preventing them from engaging in militarized conflict and war. The Liberals are based on Keohane and Nye's [8] complex interdependence approach, on the role of International Institutions as well as on Democratic Peace.

On the other hand, regarding the theoretical aspect of Realism, according to Grieco [1] states do not focus only in absolute gains, as liberals argue, but they also about relative gains. As Grieco mentions, "For realists theory, state efforts to cooperate entails these dangers plus the much greater risk, for some states, that cooperation might someday result in lost independence or security" [1]. In addition, according to Gilpin [2], those who agree with the argument that today's economic interdependence has changed the environment and the nature of international politics, should be more skeptical, since groups and states have managed to increase their gains through economic growth and international cooperation. More specifically, Hirschman's [9] hypothesis that a stable economic growth and a global economic market would diminish the struggle for power between states through cooperation and profitability did not confirm, since economic interdependence and mutual gains has not yet diminished state's efforts for promoting their national interests against the others. 
In addition, Krasner [10] by examining the US foreign Policy towards American investment in raw materials divides the state and the national interest from society. He argues that a state is an autonomous entity which promotes the national interest; therefore the state's behavior cannot be explained by class interests. Therefore, society's interests are not always identified with the national interests. Mastanduno's argument in "Economics and Security" [3] is that economic policies are supportive of security issues and that they are primarily based on three variables. The first is the structure of the International System, the second is the role of policy-makers and the third is the state's position in international economic competition. Therefore, economy is a tool of foreign policy which should be used according to state's strategic principles. According to the Realists, such as Gowa and Mansfield [11], what applies to the international system also applies to trade policy. That is to say that there is a security risk, which derives from the anarchy in the international system, which makes states act as rational players. In addition, Mansfield [11], focusing on the state-centric approach about international trade argued that the relative gains which derive from trade are used in order to maximize military force. Trade can bring resources for defense by enhancing the military power of the members involved. Therefore, a state would rather choose an ally or a friend for trade than a foe. However, Oneal and Russett [12] argued that trade is a sufficient factor which is able to reduce conflict between dyads and conclude that trade has major benefits for contiguous dyads but little effect on irrelevant dyads and interdependence decreases the likelihood of militarized disputes between major powers.

Morrow [13], examined how trade affects conflicts through a game-theoretic approach, focusing on the reasons for which an interstate conflict occurs and escalates. It is his view that the common argument is that international trade affects conflict and, more specifically, prevents states from taking military actions because of the high costs which are going to be faced in the event of a reduction in their commercial relations. However, according to game-theoretic models, there are unobservable factors which make trade effectiveness seem vague because both of the rival states try to interpret the opponent's resolve. Therefore, his argument is that the escalation of the conflict depends on what one side believes about the relative resolve of the other and the correlation between trade and conflict is the result of anticipation by economic actors, since trade flows reflect relations between two countries in a wider sense Gartzke, $\mathrm{Li}$ and Boehmer [14] examined how economic interdependence contributes to peace. Their main argument is that economic costs and benefits are not enough to deter militarized conflict between states unless capital interdependence is high. Hegre [15] also argued that in symmetric dyads, trade reduces conflict. Therefore, "trade efficiency" is more likely to happen in terms of symmetric dyads than asymmetric. According to many researchers, like Li and Sacko [16], trade between two rival states tends to decrease either because of territorial disputes or other conflictual actions. On the other side, states with cooperation on mutual gains and interests trade more than others and consequently, "trade follows the flag". Long and 
Leeds [17] examined the commercial activity of states within military alliances with or without economic provisions. As many scholars have shown, trade among allies is at higher level than trade among non-allies. The authors' main argument is that there is a connection between security and trade agreements; this helps the states overcome their problems and raise the level of co-operation between them. More specifically, they argue that when in an alliance there are military provisions coupled with economic provisions, the states are likely to trade more with each other than compared with states that are in a strictly military alliance.

Gelpi and Grieco [18] on the other hand, by examining different data through a time series analysis between democratic and autocratic states between 1950 and 1992, argued that since trade promotes economic growth, there is a high political cost for democratic leaders to initiate a military conflict with trading partners. However, this does not apply for the autocratic states. Therefore, trade dependence in general "is not a constraint on the conflict behavior of autocratic leaders"; hence trade by itself cannot prevent military conflict.

Maoz [19] developed a Social Network Analytic Approach in order to measure economic interdependence across levels of analysis, by measuring the cost of breaking economic ties. He argued that the Liberal paradigm is confirmed regarding the effects of strategic and economic interdependence on conflict.

Herge, Oneal and Russet [20] focused on the interaction between the effects of conflict and trade, giving a new approach which enriches the Liberals' theory and shows that trade promotes peace. Their main argument is that trade promotes peace but at the same time it is reduced because of conflict and this can be shown if the gravity model can be taken into consideration in conflict analysis. They also base their argument on economic interdependence, mentioning that conflict and violence in general has a significant effect on commercial relations and this, in cost and benefits terms, makes trade disruption unprofitable and consequently peace is promoted. Li and Reuveny [21] argued that their theoretic model predicts the impact of bilateral trade on conflict and a combination of imports and exports in specific sectors of commercial relations such as agriculture and fisheries, energy, chemicals and minerals goods, can determine the state's intention concerning conflict. Goldsmith [22] argued that trade interdependence mainly affects the onset of the conflict by inhibiting militarized disputes and has no relationship with conflict escalation and therefore trade volume reduces the likelihood of a more violent conflict.

\section{Analytical Framework}

Up to now, the independent variables of low politics defined the analytical framework under which Liberals supported their arguments, and they examined their hypotheses through econometric models and statistical analysis. More specifically, alliances, trade flows, Gross Domestic Product, contiguity as well as political regime have been the most common variables, among others, used by the Liberals as observable factors. Some other authors differentiated their approach 
by taking into consideration variables such as trade expectations [23], common interests [16], interaction between domestic politics and the international system [24], income ratio [25], as well as Preferential Trade Agreements [7] [20]. There are also some differences regarding the dependent variable since some of the Liberals have considered trade to be the dependent variable [17] [26] compared to others [12] [14] [21] [23] [25] [27], who considered Militarized Interstate Disputes (MIDs) as the dependent variable.

Nevertheless, they do not consider the state as a determinant, emphasizing only on economic factors which act independently. This is an important omission, since they are examining interstate conflicts. For example, Morrow [13] examines trade flows, contiguity, military capabilities and political regime without taking into consideration the state's position in the international system and the national interest. Furthermore, Liberals do not highlight the causes of conflict. Instead, they examine means of conflict resolution, based on secondary types of power, such as economic interdependence, through trade and foreign direct investments without mentioning determinants of power, such as levels of influence or military power. In addition, Liberals only argue about the pacific benefits of trade but they do not mention the impact of these effects on relative gains and a state's sovereignty.

That is to say that if a state in conflict chooses to raise trade levels with its rival, in order to avoid conflict escalation and war, this means that it shares its relative gains and this can lead to the loss of its sovereignty. For example, Long and Leeds [17] argue that the linkage of Economic and Security issues can raise trade levels but they do not refer to the impact of this linkage on the state's dynamics and its ability to promote its influence. Last but not least, Liberals seem to care more about peace and stability than about a state's sovereignty and survival within the international or regional system. That is because they examine this issue only from an economic viewpoint, trying to raise trade to the sphere of high politics. What is not mentioned is that trade, institutions and other economic organizations may provide cooperation among states but their operation is limited, since these institutions did not arise spontaneously from independent economic actors, but were the result of interstate negotiations and agreements through which powerful states could secure their domination and promote their influence to their competitors. For example, although Gartzke, Li and Boehmer [14] argue that capital interdependence reduces uncertainty and promotes conflict resolution without military actions, what is really happening is that a state shares its relative economic gains with its rival through commercial relations, and this has a direct cost on the influence field.

For our research, we take into account variables which show the correlation between economic interdependence and national interest. More specifically, macroeconomic indicators such as bilateral trade in goods and services and bilateral Foreign Direct Investments are used, which show the interdependence between the two rivals. With bilateral trade we mean the exchange of goods between two states (countries) promoting trade and investment. The two countries 
will reduce or eliminate tariffs, import quotas, export restraints, and other trade barriers to encourage trade and investment. In addition, indicators of military power such as the military expenditure and the number of sovereignty disputes and violations show the configuration of the conflict and they are variables of the state's national security.

We implement linear regressions in order to examine the correlation among these variables and even more as explained in the relevant section below. In order to investigate the existence of evidence that supports any of the aforementioned school, i.e. Realism or Liberalism, we apply it to the case of the relations of Greece with Turkey. As we realize, our findings primarily support the beliefs of Realism.

\subsection{The Impact of Economic Interdependence in the Greek-Turkish Relations (Figure 1)}

The conflict between Greece and Turkey has part of its roots back in 1821, when the Greek national uprising against the Ottoman Empire started, becoming the starting point of the movement for Greek Independence which was completed with the establishment of the Greek State as an independent state in 1830 [28]. Since then, there have been intervening wars such as World War I and World War II. As a result there has not been a stable status-quo. The final national boundaries were set at the end of World War II. Consequently, the initiation of the conflict, although old, will be considered from that time onwards.

By the end of World War II, and more specifically by 1947, Greece had expanded its territorial influence and borders, since under the Treaty of Lausanne of 1923 [29], it could regain the islands of the Aegean, and more specifically the

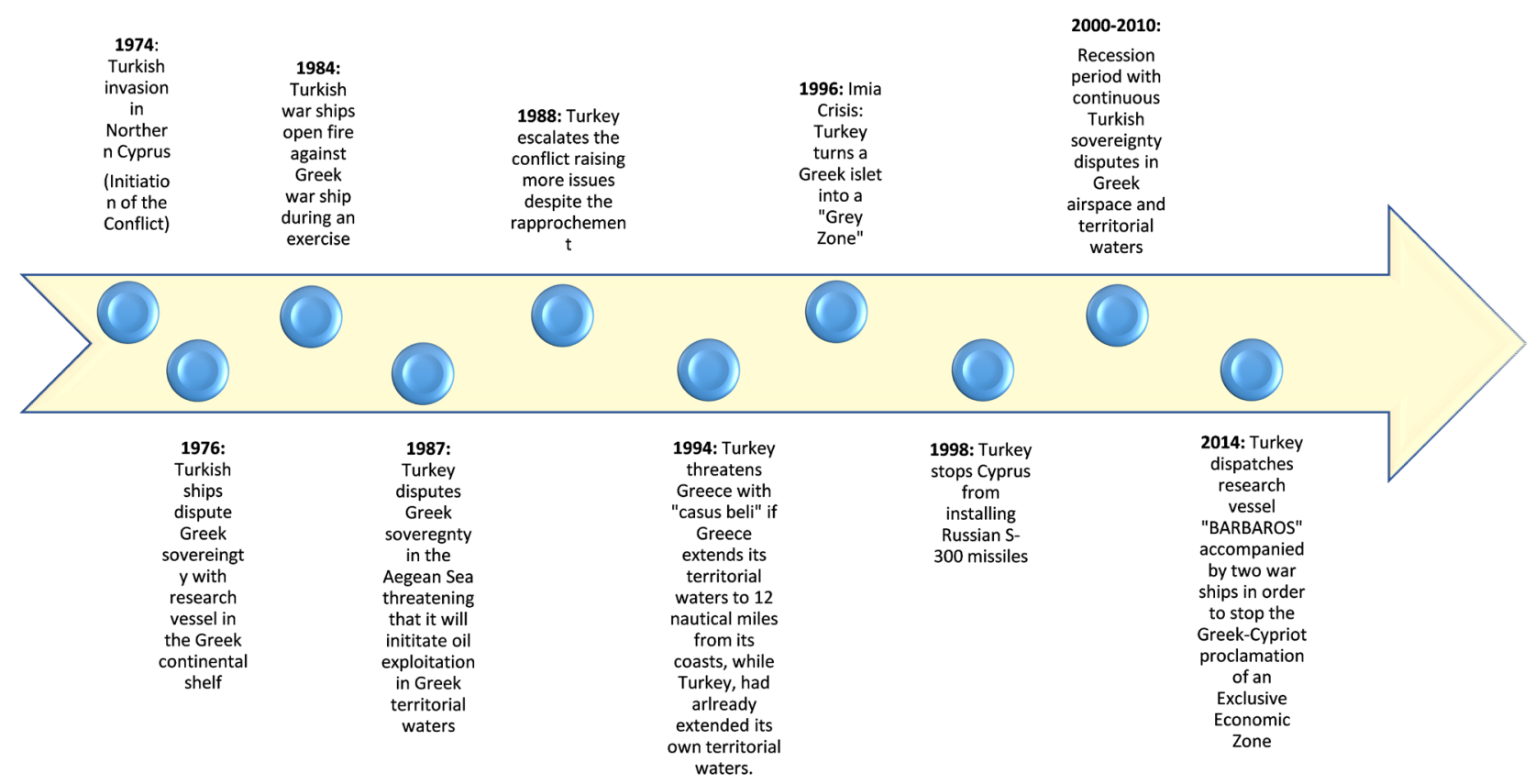

Figure 1. Timeline of the Greek-Turkish conflict. Note: Designed by the authors to map the timeline of the most significant events. 
Dodecanese, in exchange for keeping them demilitarized. In addition, what was really important was the fact that Greece raised its relative gains compared to Turkey since it could expand its maritime sovereignty to twelve nautical miles and completely restrict Turkey's access to the Aegean Sea [30]. However, Greece did not take that action. On the contrary, in 1952 both countries became members of NATO [31] in order to promote better relations against their common rival but for Greece it was also a method of balancing its power against that of Turkey.

Nevertheless, peaceful relations with Turkey did not last long. The strained relations in Cyprus between the Greek and the Turkish communities, aggravated by British actions, played a crucial role. More specifically, Great Britain implemented a "divide and rule" strategy in Cyprus. Despite the fact that Great Britain ruled over Cyprus absolutely as a colony and had great influence there, it decided to engage the Turkish side more in order to restrict Greek claims, which concerned the union of Cyprus with Greece [30]. As a result, in 1959 both the Greek and the Turkish sides signed the Zurich and London Agreement, according to which Cyprus was to become an independent democratic state while the British side would retain its sovereignty over two areas where its military bases were located. On the other hand, the Greek and Turkish side could also maintain small parts of their troops.

This move put the Greek influence over Cyprus in danger since the latter was trying to establish its independence further and at the same time Turkey was trying to promote its interests by extending its influence over Cyprus and increasing its gains by controlling that area. Moreover, in order to exert more pressure on Greece, Turkey became more aggressive, ignoring the Greek sovereignty over the Aegean Sea, and started prospecting for oil in areas of the Greek continental shelf. The escalation of this conflict brought about the Turkish invasion of North-East Cyprus which resulted in the occupation of $36.4 \%$ of the island by Turkish troops, which continues to this date.

According to the Hellenic ministry of foreign affairs, starting with the dispute over the delimitation of the continental shelf (1973) and the crisis that followed -bringing the two countries into intense disagreement, which was taken in hand, on Greece's initiative, by both the UN Security Council and the International Court in the Hague-Turkey started to implement the policy of constantly increasing contentions and claims, including:

- Contesting Greece's legal right, on threat of war (casus belli), to extend its territorial sea to 12 nautical miles, as provided for by the Law of the Sea, and as has been done by virtually all coastal states in the international community, including Turkey (in the Black Sea and Eastern Mediterranean)

- Disputing the extent of the Greek national airspace, through constant violations by Turkish fighter aircraft

- Contesting Greek regime and sovereignty over islands and violation of that sovereignty

- Disputing the delimitation of territorial sea 
- Disputing responsibilities within the Athinai (Athens) FIR, which were entrusted to Greece by ICAO, and refusing to comply with air traffic regulations

- Disputing Greece's jurisdiction within the search and rescue region under Greek responsibility

- Demanding the demilitarization of the islands of the Eastern Aegean Sea [32].

According to the Turkish Ministry of Foreign Affairs [33], the "Aegean Problems" concern:

- The Breadth of Territorial Waters

- The Delimitation of the Aegean Continental Shelf

- The Militarization of Eastern Aegean Sea Islands Contrary to the Provisions of International Agreements

- Air Space Related Problems

- The Islands, Islets and Rocks in the Aegean Which Were Not Ceded To Greece By International Treaties

- The Kardak Dispute

- The Search and Rescue Regions in the Aegean

- Turkey's Views Regarding the Settlement Of The Aegean Problems

- Turkey's Aegean Peace Process Initiative.

The Turkish side also raises issues of Turkish Minority of Western Thrace and the Turkish Community in the Dodecanese.

\subsection{Indicators of Economic Interdependence}

\subsubsection{Trade}

Although Greece tried to raise the levels of its economic power focusing on exports, the balance of trade with Turkey was negative. Figure 2 below shows one of the most important indicators of economic interdependence, which is bilateral trade between rivals. More specifically, the balance of trade did not have large deviations regarding the value of imports and exports, since both were at low

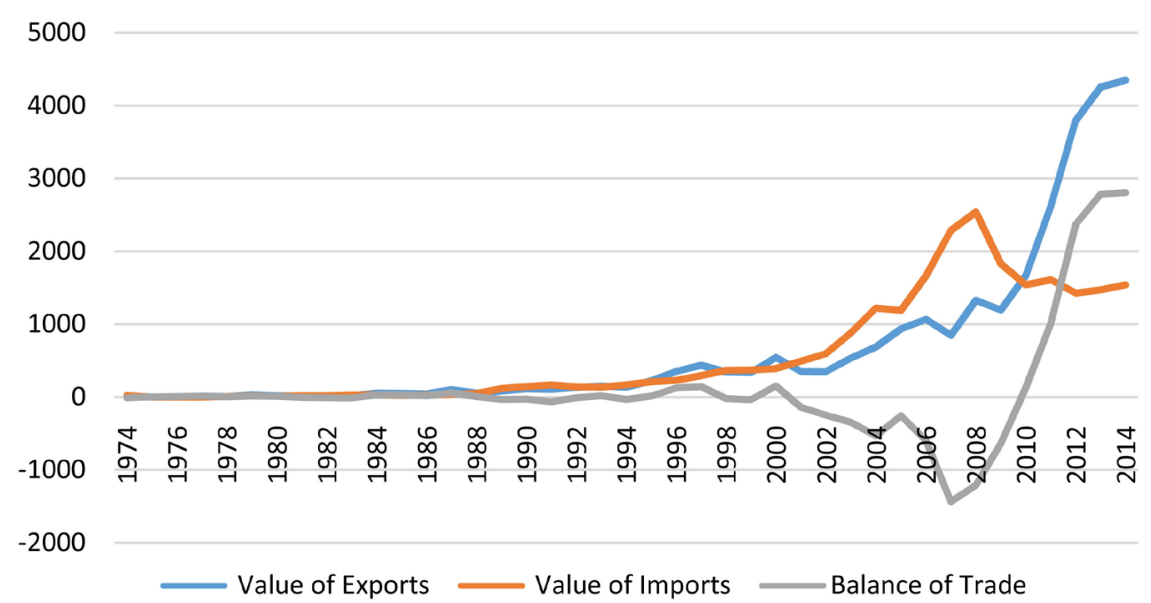

Figure 2. Bilateral trade 1974-2014 Greece to and from Turkey (in million USD). Source: UN Comtrade, 2015. 
levels. Nevertheless, from 2001 to 2010 the imports from Turkey exceeded exports, reaching 2541.19 million USD in 2008 while exports, in the same year stood at 1328.96 million USD, almost half of the value of imports. From 2010 onwards, Greek exports to Turkey rose and their value reached 4348.02 million USD although at the same time imports were decreasing, reaching 1543.47 million USD.

In addition, from 2004 to 2013 Turkey became Greece's number 1 export partner. More specifically, according to Table 1 in 2004 the value of Greek exports to Turkey was 690.95 million USD and in 2013 that figure had reached 4228.20 million USD. That is to say from 2004 to 2013 Greek exports to the Turkish market rose by $512 \%$.

\subsubsection{Foreign Direct Investments}

One more important indicator is Foreign Direct Investments (FDI). As Figure 3 shows, the absence of Turkish investments in Greece is noticeable. In 2001 both

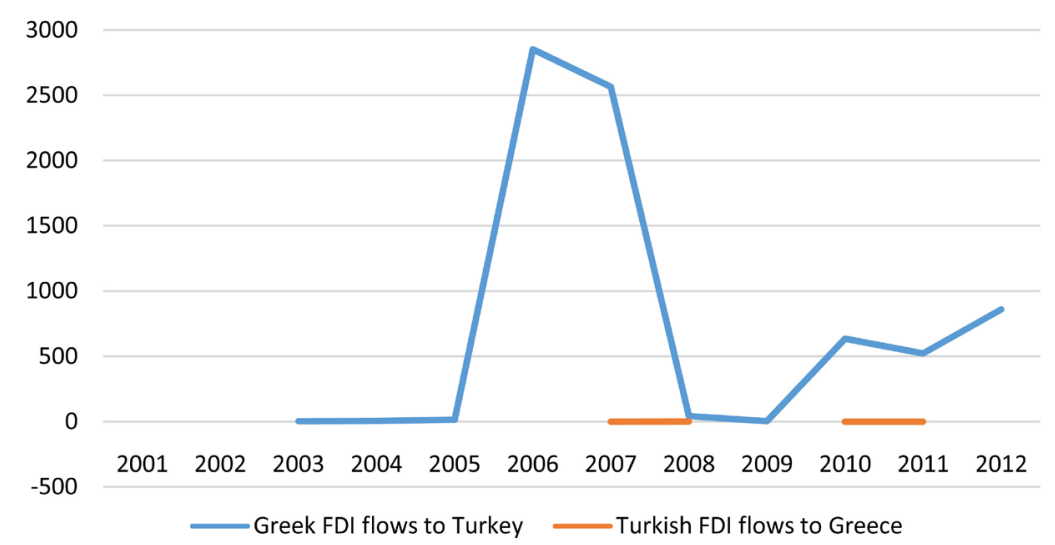

Figure 3. FDI flows 2001-2012 (in million USD). Source: UNCTAD, 2018.

Table 1. Greece's top ten exports partners 2004-2013 (in million USD).

\begin{tabular}{|c|c|c|c|c|c|c|c|c|c|c|c|}
\hline & 2004 & 2005 & 2006 & 2007 & 2008 & 2009 & 2010 & 2011 & 2012 & 2013 & $\begin{array}{c}\text { Growth rate of } \\
\text { Greek exports } \\
\text { (2004-2013) (\%) } \\
\text { Appr. }\end{array}$ \\
\hline Turkey & 690.95 & 918.27 & 1062.65 & 1035.14 & 1327.54 & 1199.93 & 1652.58 & 2597.56 & 3769.09 & 4228.20 & $512 \%$ \\
\hline Italy & 1571.35 & 2080.22 & 2556.93 & 2841.64 & 3248.82 & 2509.19 & 2591.66 & 3205.66 & 2735.51 & 3256.97 & $107 \%$ \\
\hline Germany & 1999.87 & 2368.83 & 2624.76 & 3015.79 & 3074.84 & 2511.78 & 2598.38 & 2658.45 & 2271.32 & 2379.92 & $19 \%$ \\
\hline Bulgaria & 969.51 & 1012.91 & 1319.13 & 1619.15 & 2049.14 & 1484.92 & 1525.08 & 1861.83 & 2008.03 & 1921.01 & $98 \%$ \\
\hline Cyprus & 706.78 & 1093.88 & 1227.23 & 1720.65 & 1977.50 & 1665.56 & 1927.62 & 2171.01 & 1821.24 & 1626.87 & $130 \%$ \\
\hline $\begin{array}{l}\text { United } \\
\text { Kingdom }\end{array}$ & 1145.56 & 1281.83 & 1353.08 & 1431.58 & 1421.17 & 1033.28 & 1342.73 & 1387.73 & 1105.52 & 1301.13 & $14 \%$ \\
\hline United States & 811.53 & 913.88 & 911.44 & 1140.97 & 1607.40 & 1208.65 & 1026.12 & 1676.74 & 1172.45 & 1081.23 & $33 \%$ \\
\hline FYROM & 385.59 & 406.63 & 471.19 & 542.31 & 670.78 & 570.46 & 513.63 & 774.03 & 1049.78 & 979.31 & $154 \%$ \\
\hline Libya & 211.16 & 198.63 & 280.06 & 238.56 & 196.20 & 359.02 & 693.83 & 213.42 & 929.42 & 900.92 & $327 \%$ \\
\hline France & 643.31 & 820.27 & 1033.84 & 1082.08 & 1096.52 & 824.98 & 878.28 & 967.71 & 867.24 & 859.74 & $34 \%$ \\
\hline
\end{tabular}

Source: Direction of Trade Statistics (DOTS), 2018 [41]. 
countries signed a Bilateral Investment Promotion and Protection Agreement and investment plans were increased. More specifically, in 2006 and 2007 the Greek investments in Turkey were 2853 and 2566 million USD respectively, resulting in more than 80 Greek businesses being set up in the Turkish market [34]. On the other hand, Turkish FDIs highest point was in 2008 with 2 million USD.

In addition to Foreign Direct Investments Flows, Figure 3 illustrates inwards flows as a percentage of GDP in order to show the value of Greek investments into the Turkish economy. More specifically, the total of inward flows of FDI into Turkey in 2006 was 3.8\% of GDP and in the same year, Greek flows into Turkey were 2853 million USD, meaning that it was only $0.53 \%$ of the Turkish GDP. The same can be said also for the years 2007 and 2012. In 2007 Greek flows into Turkey stood at 2566 million USD, which is to say $0.39 \%$ of GDP and in 2012 they reached 860 million USD, which accounted for $0.1 \%$ of the Turkish GDP.

Summarizing, we realized that economic interdependence between two rivals can be shown by indicators such as bilateral trade and foreign direct investments. Regarding the first indicator, the most significant point is that Turkey is the number 1 export partner for Greece, which means that it is also an important market for Greek products. Regarding foreign direct investments, although there is some economic activity the rates remain at a very low level and therefore data are not sufficient enough to reach accurate results.

\subsection{Bilateral Military Relations}

\subsubsection{Military Expenditure}

Turkey's Military Expenditure from 1988 to 2013 was higher relative to Greece's. According to Figure 4 below, in 1988 Turkey was spending 9397 mil. USD and ten years later Military Expenditure reached 19,280 mil. USD, meaning that it rose by $105.1 \%$. From 1999 to 2005 there was a small decrease by $26.3 \%$, however, from 2005 onwards Military Expenditure began increasing again by $19.2 \%$,

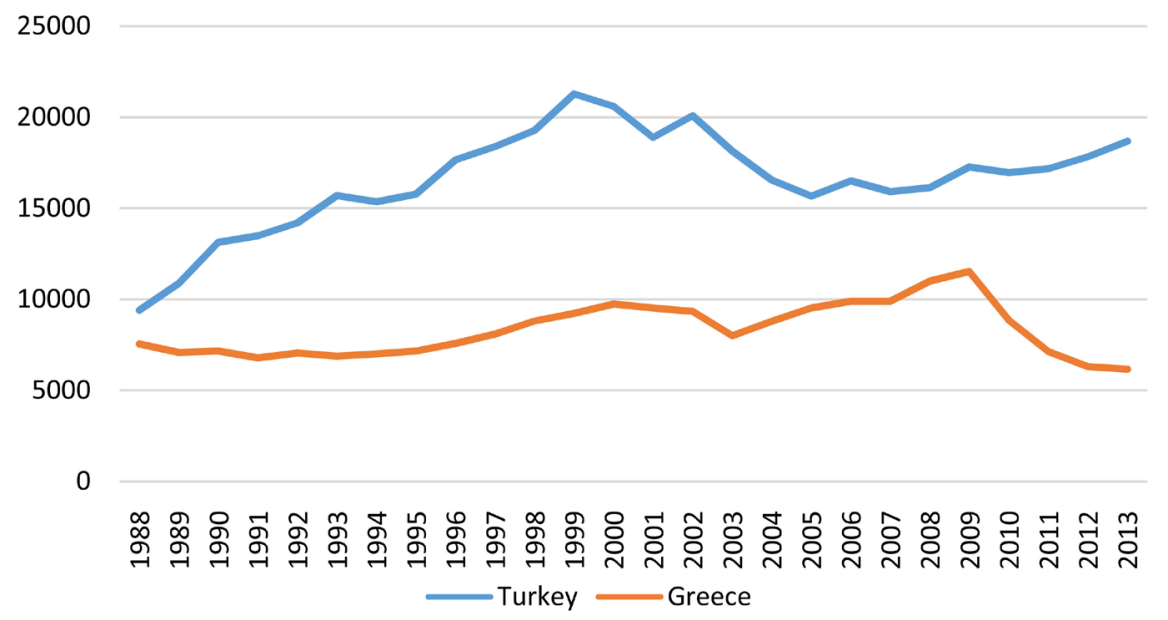

Figure 4. Military Expenditure, million USD (1988-2013). Source: SIPRI, 2015. 
reaching 18,682 mil. USD in 2013.

More specifically, Greece raised its expenditure from 1988 to 2009 by 52.4\%, while Turkey, during the same years, raised its expenditure by $83.8 \%$. Nevertheless, because of the financial and debt crisis in 2010 [35] [36], Greece was forced to decrease its Military Expenditure by 46.4\%, reaching 6, 177 mil. USD in 2013, a figure which was lower than that in 1988, which was 7562 mil. USD.

In addition, although Turkish spending began to gradually decrease from 2002 onwards, Turkey spent around 20,094 million USD on defense spending whereas Greece at the same time was spending 9347 million USD. Consequently, a disproportionate situation like this usually leads the weaker side to continually increase its spending not just to procure arms but also as a means of directly responding to the other side, so as to provide better deterrence. Nevertheless, the feeling of insecurity for both countries, and especially for Greece, increased and still remains high. However, the decline in the last six years is due to Greece's obligations towards the support mechanism which Greece joined in 2010 [35].

\subsubsection{Violations and Disputes}

There continue to be high levels of Turkish violations and disputes, despite Greek efforts at deterrence and balancing. More specifically, according to the available data in Figure 5, most of the violations concern Greek national airspace, especially in the Northern, Central and Southern Aegean Sea. From 1996 to 2003 Turkish violations increased from 1689 to 3938 , with some fluctuations during those years. Ten years later, from 2004 to 2014, although Turkish violations had decreased, they remained high.

For example, despite the Greek-Turkish rapprochement and the de-escalation in the conflict from 2000 to 2010, the violations were increasing remarkably. More specifically, in 2008 the violations of Greek national airspace decreased to 1288, however, from 2009 onwards they increased again, especially from 2013 to 2014 and Turkey also reinforced its disputes with further violations of Greek territorial waters and infringements of Air Traffic Regulations from 1999 onwards.

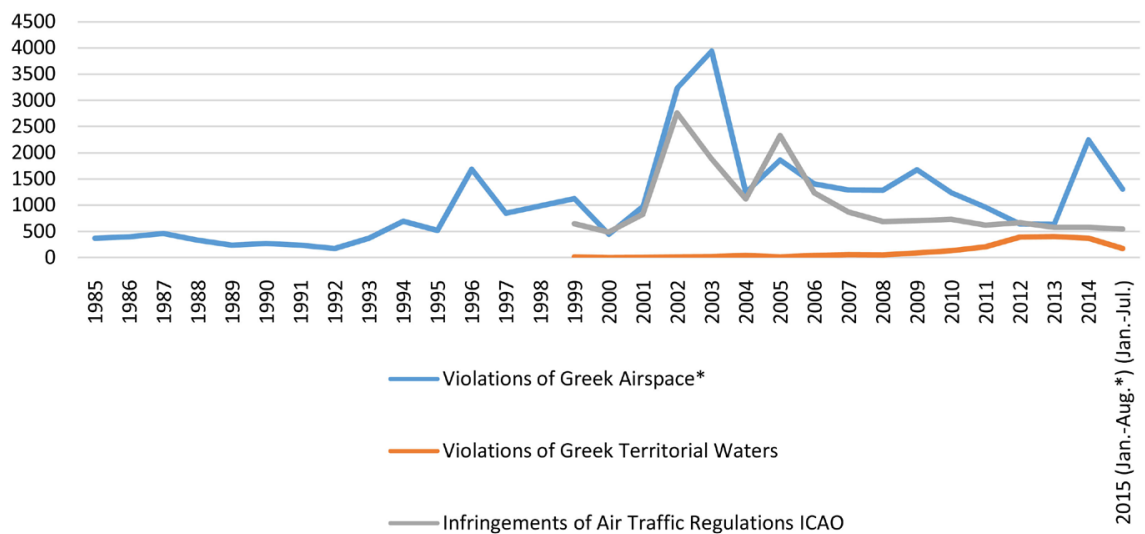

Figure 5. Turkish violations of Greek sovereignty. Sources: 1985-1999: Kollias, 2004, 1999-2008: Hellenic ministry of foreign affairs-directorate A4: Turkey, 2015, 2009-2015: Hellenic national defense general staff, 2018 [37]-[46]. 
The violation of Greek territorial waters is part of the Turkish claims about the breadth of the territorial waters and the delimitation of the continental shelf. Despite the fact that all Turkish aircrafts and vessels are always recognized and suspended in accordance with international rules, Turkey escalates the conflict in order to make its threat credible. In that way, Turkey uses military forces and not only political statements or other diplomatic tools in order to show its intentions and escalate the conflict, by disputing Greek sovereignty both in terms of airspace and the sea.

Summarizing, regarding the bilateral relations between the two rivals, none of them possess nuclear weapons and therefore their military power is determined by conventional weapons. Turkey's Military Expenditure is higher than Greece's, therefore, its military capabilities are higher, so we can conclude that Turkey is a greater military power than Greece. However, despite the fact that both of them belong to the same military alliance, that is not enough for Greek national security since there are a large number of continuous Turkish violations of Greek national airspace and territorial waters and in many cases these violations turn into "hot" incidents.

\section{Regression Analysis}

In order to quantitatively investigate and substantiate our reasoning we perform a regression analysis among measures of national security threat and indicators of economic interdependence. We try to increase the aforementioned indicators with the ones that seem relevant. Moreover, we investigate the potential relation of the national security threat measures with the relative power or weakness of the economies of the states of interest.

\subsection{Data, Variables and Methodology}

\subsubsection{Data}

Our dataset consists of Total Number of Violations of Greece from Turkey, which consists of the Violations of Greek Airspace, the Violations of Greek Territorial Waters and Infringements of Air Traffic Regulations (International Civil Aviation Organization-ICAO) and the Defense Expenses of Greece as a percent of its GDP, which are taken from the Hellenic National Defense General Staff [43].

The macroeconomic variables are taken from the World Bank [37] and the OECD [38], as well as the Comtrade [39] [40].

\subsubsection{Variables}

The variables that are used as measures of national security threat are the 1) Total Number of Violations of Greece from Turkey, which consists of the Violations of Greek Airspace, the Violations of Greek Territorial Waters and Infringements of Air Traffic Regulations (International Civil Aviation Organization-ICAO); 2) the Violations of Greek Airspace (as these are the majority of the recorded violations) from Turkey; and 3) the Defense Expenses of Greece as 
a percent of its GDP, considering that the main threatening party is Turkey and thus the increase or drop of the Defense Expenses of Greece as a percent of its GDP stems primarily from the stance of Turkey. These are the dependent variables of our model. The rationale behind the choice of these variables is that the threat of national security is expressed primarily through violations of the land, water and airspace boarders. In the case of Greece and Turkey it is primarily via the third and the second and not really through the first.

We use as indicators of economic interdependence the Exports of Greece to Turkey, the Imports of Greece from Turkey, the Bilateral Trade, the Greek FDI flows to Turkey, the Turkish FDI flows to Greece, the Exports of Greece as a percent of its GDP to Turkey and the Exports of Turkey as a percent of its GDP to Greece. These are the independent variables of our model. The reasoning behind the choice of these variables is that they indicate economic activity between the two countries. Our intention is to investigate whether such interdependence eliminates the threat of national security or not. The variables used are presented in Table 2.

In addition, we attempt to find whether there is a link between the national security threats and the relative power or weakness of one economy over the other. The variables we use as measures of national security are the same as before. The relative power is measured by the GDP of Turkey/GDP of Greece, the GDP growth of Turkey/GDP growth of Greece, the GDP per capita of Turkey/GDP per capita of Greece, the Total Reserves of Turkey/Total Reserves of Greece, the Exports as a percent of GDP of Turkey/Exports as a percent of GDP of Greece, the Balance of Trade of Turkey/Balance of Trade of Greece, the Defense Expenditure of Turkey/Defense Expenditure of Greece, the Debt as a percent of GDP of Turkey/Debt as a percent of GDP of Greece, the Unemployment of Turkey/Unemployment of Greece, the Market Cap as a percent of GDP of Turkey/Market Cap as a percent of GDP of Greece, the Market Cap of Turkey/ Market Cap of Greece, the FDI (Net Inflows) as a percent of GDP of Turkey/FDI

Table 2. Economic interdependence variables.

\begin{tabular}{cc}
\hline Dependent Variables & Independent Variables \\
\hline Total Number of Violations & Exports of Greece to Turkey \\
Violations of Greek Airspace & Imports of Greece from Turkey \\
Defense Expenses of \\
Greece as a percent of its GDP
\end{tabular}

Sources: 1985-1999: Kollias, 2004, 1999-2008: Hellenic Ministry of Foreign Affairs-Directorate A4: Turkey, 2015, 2009-2015: Hellenic National Defense General Staff, 2018, SIPRI, 2015, World Bank, 2017, UNcomtrade, 2015, UNCTAD, 2018 [43] [44] [45]. 
(Net Inflows) as a percent of GDP of Greece, and the Defense Expenses as a percent of GDP of Turkey/Defense Expenses as a percent of GDP of Greece. These are our independent variables. The rationale for the choice of these independent variables is that they measure whether an economy performs better than the other historically. We attempt to examine whether the relative power of the economy of the threatening party affects the national security threats towards the threatened state. The variables used are presented in Table 3.

\subsubsection{Methodology}

We attempt the use of linear regression in order to link the measures of national security threats with the indicators of economic interdependence in the first set of regressions and with the determinants of the relative power or weakness of one economy in the second set of regressions. The regressions we run use one dependent and one independent variable. The general form of the regression equation is:

$$
\text { National Security Threat }=\beta_{0}+\beta_{1} \cdot E I R S+u,
$$

where National Security Threat is any of the above variables that reflect the

Table 3. Relative economic power variables.

\begin{tabular}{|c|c|}
\hline Dependent Variables & Independent Variables \\
\hline Total Number of Violations & GDP of Turkey/GDP of Greece \\
\hline Violations of Greek Airspace & GDP growth of Turkey/GDP growth of Greece \\
\hline \multirow[t]{11}{*}{$\begin{array}{c}\text { Defense Expenses of } \\
\text { Greece as a percent of its GDP }\end{array}$} & GDP per capita of Turkey/GDP per capita of Greece \\
\hline & Total Reserves of Turkey/Total Reserves of Greece \\
\hline & $\begin{array}{c}\text { Exports as a percent of GDP of } \\
\text { Turkey/Exports as a percent of GDP of Greece }\end{array}$ \\
\hline & Balance of Trade of Turkey/Balance of Trade of Greece \\
\hline & $\begin{array}{c}\text { Defense Expenditure of } \\
\text { Turkey/Defense Expenditure of Greece }\end{array}$ \\
\hline & $\begin{array}{c}\text { Debt as a percent of GDP of } \\
\text { Turkey/Debt as a percent of GDP of Greece }\end{array}$ \\
\hline & Unemployment of Turkey/Unemployment of Greece \\
\hline & $\begin{array}{l}\text { Market Cap as a percent of GDP of } \\
\text { Turkey/Market Cap as a percent of GDP of Greece }\end{array}$ \\
\hline & Market Cap of Turkey/Market Cap of Greece \\
\hline & $\begin{array}{l}\text { FDI (Net Inflows) as a percent of GDP of } \\
\text { Turkey/FDI (Net Inflows) as a percent of GDP of Greece }\end{array}$ \\
\hline & $\begin{array}{l}\text { Defense Expenses as a percent of GDP of } \\
\text { Turkey/Defense Expenses as a percent of GDP of Greece }\end{array}$ \\
\hline
\end{tabular}

Sources: 1985-1999: Kollias, 2004, 1999-2008: Hellenic Ministry of Foreign Affairs-Directorate A4: Turkey, 2015, 2009-2015: Hellenic National Defense General Staff, 2018, SIPRI, 2015, World Bank, 2017, UNcomtrade (a), 2015, UNCTAD, 2018,OECD, 2017. 
threat and EIRS is any of the variables that determine the economic interdependence or relative power, $\beta_{1}$ denotes the coefficient, $\beta_{0}$ denotes the constant term and $u$ denotes the stochastic error term. We use the Stata econometric software to run these linear regressions with Ordinary Least Squares (OLS). We use White's test to detect potential heteroskedasticity and we use Robust Standard Errors to tackle it when present.

\subsection{Regressions}

We regressed each of the independent variables with each of the dependent variables that as shown in Table 4 and Table 5 and explained in the results section below.

\subsection{Results and Implications}

We regressed the total number of violations with the exports of Greece to Turkey, the imports of Greece from Turkey, the bilateral trade, the Greek FDI flows to Turkey, the Turkish FDI flows to Greece, the exports of Greece as a percent of its GDP to Turkey, the exports of Turkey as a percent of its GDP to Greece individually. We realized that the total number of violations are positively correlated with the imports of Greece from Turkey and the exports of Turkey as a percent of its GDP to Greece at all significance levels, the exports of Greece to Turkey and the exports of Greece as a percent of its GDP to Turkey at the 5\% significance level, whereas the remaining variables have no statistical significance. This means that as economic interdependence, as measured by the exports of Greece to Turkey, its imports from Turkey and the exports of one country to the other as a percent of their GDP, the number of total violations increases.

We regressed the violations of the Greek airspace with the same independent variables individually to find that they are positively correlated at all significance levels with the exports of Turkey as a percent of its GDP to Greece and at the 5\% level with the imports of Greece from Turkey. The remaining variables post no statistical significance. This once and again implies that the increase of economic interdependence between the two countries leads to an increase of the violations of the Greek airspace.

We regressed the defense expenses of Greece as a percent of its GDP with the same independent variables to see that they are positively correlated with the exports of Turkey as a percent of its GDP to Greece at all significance levels, the imports of Greece from Turkey at the 5\% significance level and the Turkish FDI flows to Greece at the $10 \%$ significance level. The rest of the variables exhibit no statistical significance. This shows that the increase of economic interdependence between the two countries leads to an increase of the defense expenses of Greece as a percent of its GDP.

The aforementioned findings indicate that as economic interdependence increases the measures of national security threat increase as well. Consequently, economic interdependence does not seem to promote peace. This is in line with 
Table 4. Regressions summary economic interdependence variables.

\begin{tabular}{|c|c|c|c|c|c|c|c|}
\hline Variables/Regressions & 1 & 2 & 3 & 4 & 5 & 6 & 7 \\
\hline \multicolumn{8}{|l|}{ Dependent Variables } \\
\hline Total Number of Violations & $\mathrm{X}$ & $\mathrm{X}$ & $\mathrm{X}$ & $\mathrm{X}$ & $\mathrm{X}$ & $\mathrm{X}$ & $\mathrm{X}$ \\
\hline \multicolumn{8}{|l|}{ Independent Variables } \\
\hline Exports of Greece to Turkey & $\begin{array}{l}0.4569545^{* *} \\
\quad(2.19)\end{array}$ & & & & & & \\
\hline Imports of Greece from Turkey & & $\begin{array}{l}1.165304^{* * *} \\
(4.00)\end{array}$ & & & & & \\
\hline Bilateral Trade & & & $\begin{array}{l}-0.015125 \\
(-0.05)\end{array}$ & & & & \\
\hline Greek FDI flows to Turkey & & & & $\begin{array}{c}-0.3183067 \\
(-0.78)\end{array}$ & & & \\
\hline Turkish FDI flows to Greece & & & & & $\begin{array}{c}-32.16667 \\
(-0.33)\end{array}$ & & \\
\hline $\begin{array}{c}\text { Exports of Greece as a percent } \\
\text { of its GDP to Turkey }\end{array}$ & & & & & & $\begin{array}{l}112,169.1^{* *} \\
(2.08)\end{array}$ & \\
\hline $\begin{array}{c}\text { Exports of Turkey as a percent } \\
\text { of its GDP to Greece }\end{array}$ & & & & & & & $\begin{array}{l}1,163,959^{* * *} \\
\quad(6.70)\end{array}$ \\
\hline Constant & $\begin{array}{l}1110.926^{* * *} \\
(3.74)\end{array}$ & $\begin{array}{l}679.3621^{* *} \\
(2.31)\end{array}$ & $\begin{array}{c}1483.78^{* * *} \\
(5.65)\end{array}$ & $\begin{array}{l}2985.848^{* * *} \\
(5.73)\end{array}$ & $\begin{array}{l}2095.333^{* * *} \\
(17.20)\end{array}$ & $\begin{array}{l}1067.426^{* * *} \\
\quad(3.38)\end{array}$ & $\begin{array}{c}-3,465,463 \\
(-1.08)\end{array}$ \\
\hline Observations & 36 & 36 & 36 & 10 & 5 & 36 & 36 \\
\hline Adjusted R-squared & 0.0976 & 0.3004 & -0.0293 & -0.0463 & -0.2855 & 0.0870 & 0.5564 \\
\hline Variables/Regressions & 8 & 9 & 10 & 11 & 12 & 13 & 14 \\
\hline \multicolumn{8}{|l|}{ Dependent Variables } \\
\hline Violations of Greek Airspace & $\mathrm{X}$ & $\mathrm{X}$ & $\mathrm{X}$ & $\mathrm{X}$ & $\mathrm{X}$ & $\mathrm{X}$ & $\mathrm{X}$ \\
\hline \multicolumn{8}{|l|}{$\begin{array}{l}\text { Defense Expenses of Greece } \\
\text { as a percent of its GDP }\end{array}$} \\
\hline \multicolumn{8}{|l|}{ Independent Variables } \\
\hline Exports of Greece to Turkey & $\begin{array}{l}0.1368561 \\
(1.06)\end{array}$ & & & & & & \\
\hline Imports of Greece from Turkey & & $\begin{array}{l}0.4709908^{* *} \\
\quad(2.39)\end{array}$ & & & & & \\
\hline Bilateral Trade & & & $\begin{array}{c}-0.0665562 \\
(-0.39)\end{array}$ & & & & \\
\hline Greek FDI flows to Turkey & & & & $\begin{array}{c}-0.2286313 \\
(-0.80)\end{array}$ & & & \\
\hline Turkish FDI flows to Greece & & & & & $\begin{array}{c}35.08333 \\
(0.63)\end{array}$ & & \\
\hline $\begin{array}{c}\text { Exports of Greece as a } \\
\text { percent of its GDP to Turkey }\end{array}$ & & & & & & $\begin{array}{c}32878.4 \\
(0.98)\end{array}$ & \\
\hline $\begin{array}{c}\text { Exports of Turkey as a } \\
\text { percent of its GDP to Greece }\end{array}$ & & & & & & & $\begin{array}{c}589,567.9^{* * *} \\
\quad(4.33)\end{array}$ \\
\hline
\end{tabular}




\section{Continued}

\begin{tabular}{|c|c|c|c|c|c|c|c|}
\hline Constant & $\begin{array}{l}955.8309^{* * *} \\
(4.82)\end{array}$ & $\begin{array}{c}709.3034^{* * *} \\
(3.31)\end{array}$ & $\begin{array}{l}1093.86^{* * *} \\
(6.79)\end{array}$ & $\begin{array}{c}1727.002^{\star * *} \\
(4.78)\end{array}$ & $\begin{array}{c}1217.833^{\star * *} \\
(17.34)\end{array}$ & $\begin{array}{c}945.6663^{* * *} \\
(4.48)\end{array}$ & $\begin{array}{c}40.94154 \\
(0.15)\end{array}$ \\
\hline Observations & 31 & 31 & 31 & 10 & 5 & 31 & 31 \\
\hline Adjusted R-squared & 0.0039 & 0.1354 & -0.0291 & -0.0407 & -0.1767 & -0.0011 & 0.3718 \\
\hline Variables/Regressions & 15 & 16 & 17 & 18 & 19 & 20 & 21 \\
\hline \multicolumn{8}{|l|}{ Dependent Variables } \\
\hline $\begin{array}{l}\text { Defense Expenses of Greece } \\
\text { as a percent of its GDP }\end{array}$ & $\mathrm{X}$ & $\mathrm{X}$ & $\mathrm{X}$ & $\mathrm{X}$ & $\mathrm{X}$ & $\mathrm{X}$ & $\mathrm{X}$ \\
\hline \multicolumn{8}{|l|}{ Independent Variables } \\
\hline Exports of Greece to Turkey & $\begin{array}{c}1.79 \mathrm{e}-06 \\
(0.97)\end{array}$ & & & & & & \\
\hline Imports of Greece from Turkey & & $\begin{array}{l}5.65 \mathrm{e}-06^{\star \star} \\
\quad(2.02)\end{array}$ & & & & & \\
\hline Bilateral Trade & & & $\begin{array}{c}-8.53 e-07 \\
(-0.34)\end{array}$ & & & & \\
\hline Greek FDI flows to Turkey & & & & $\begin{array}{c}-3.15 e-07 \\
(-0.38)\end{array}$ & & & \\
\hline Turkish FDI flows to Greece & & & & & $\begin{array}{l}0.0012012^{*} \\
(2.89)\end{array}$ & & \\
\hline $\begin{array}{c}\text { Exports of Greece as a } \\
\text { percent of its GDP to Turkey }\end{array}$ & & & & & & $\begin{array}{l}0.4738162 \\
\quad(1.00)\end{array}$ & \\
\hline $\begin{array}{c}\text { Exports of Turkey as a } \\
\text { percent of its GDP to Greece }\end{array}$ & & & & & & & $\begin{array}{c}7.135252^{\star * *} \\
(3.86)\end{array}$ \\
\hline Constant & $\begin{array}{c}0.0215527^{\star * *} \\
(8.23)\end{array}$ & $\begin{array}{c}0.0191112^{* * *} \\
(6.78)\end{array}$ & $\begin{array}{c}0.0231108^{* * *} \\
(10.52)\end{array}$ & $\begin{array}{c}0.0274212^{* * *} \\
(25.99)\end{array}$ & $\begin{array}{c}0.0274163^{* * *} \\
(52.19)\end{array}$ & $\begin{array}{c}0.0212549^{* * *} \\
(7.68)\end{array}$ & $\begin{array}{l}0.011797^{\star * *} \\
\quad(3.44)\end{array}$ \\
\hline Observations & 36 & 36 & 36 & 10 & 5 & 36 & 36 \\
\hline Adjusted R-squared & -0.0016 & 0.0813 & -0.0260 & -0.1051 & 0.6481 & 0.0002 & 0.2843 \\
\hline
\end{tabular}

Table 5. Regressions summary relative economic power variables.

\begin{tabular}{|c|c|c|c|c|c|c|c|c|c|c|c|c|c|}
\hline $\begin{array}{l}\text { Variables/ } \\
\text { Regressions }\end{array}$ & 1 & 2 & 3 & 4 & 5 & 6 & 7 & 8 & 9 & 10 & 11 & 12 & 13 \\
\hline \multicolumn{14}{|l|}{$\begin{array}{l}\text { Dependent } \\
\text { Variables }\end{array}$} \\
\hline $\begin{array}{l}\text { Total Number } \\
\text { of Violations }\end{array}$ & $\mathrm{X}$ & $\mathrm{X}$ & $\mathrm{X}$ & $\mathrm{X}$ & $\mathrm{X}$ & $\mathrm{X}$ & $\mathrm{X}$ & $\mathrm{X}$ & $\mathrm{X}$ & $\mathrm{X}$ & $\mathrm{X}$ & $\mathrm{X}$ & $\mathrm{X}$ \\
\hline \multicolumn{14}{|l|}{$\begin{array}{c}\text { Independent } \\
\text { Variables }\end{array}$} \\
\hline $\begin{array}{c}\text { GDP of } \\
\text { Turkey/GDP } \\
\text { of Greece }\end{array}$ & $\begin{array}{c}846.6624^{* *} \\
(2.39)\end{array}$ & & & & & & & & & & & & \\
\hline $\begin{array}{l}\text { GDP growth } \\
\text { of Turkey/GDP } \\
\text { growth of Greece }\end{array}$ & & $\begin{array}{c}15.90186 \\
(0.30)\end{array}$ & & & & & & & & & & & \\
\hline
\end{tabular}




\section{Continued}

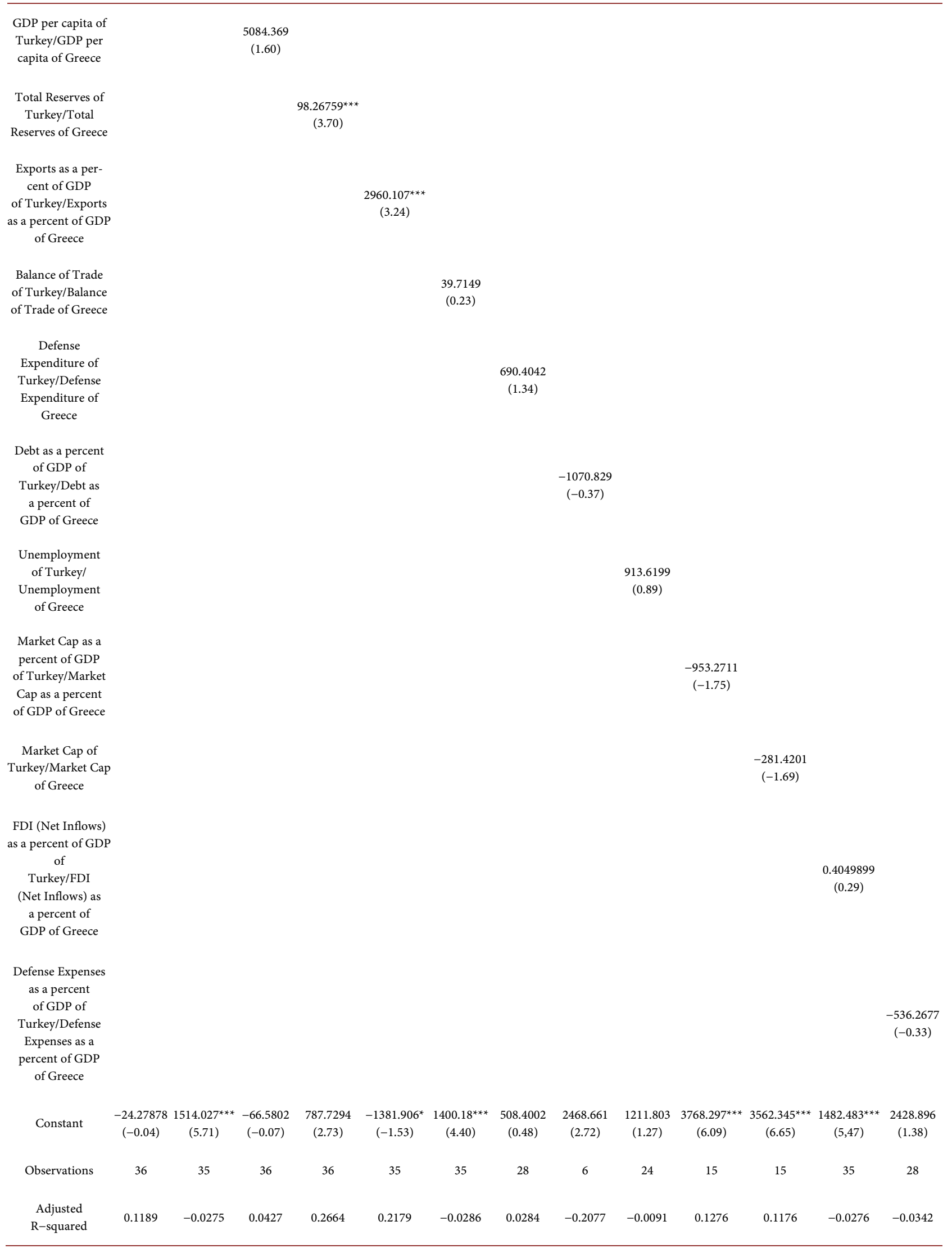




\begin{tabular}{|c|c|c|c|c|c|c|c|c|c|c|c|c|c|}
\hline $\begin{array}{l}\text { Variables/ } \\
\text { Regressions }\end{array}$ & 14 & 15 & 16 & 17 & 18 & 19 & 20 & 21 & 22 & 23 & 24 & 25 & 26 \\
\hline $\begin{array}{l}\text { Dependent } \\
\text { Variables }\end{array}$ & & & & & & & & & & & & & \\
\hline $\begin{array}{l}\text { Violations of } \\
\text { Greek Airspace }\end{array}$ & $\mathrm{X}$ & $\mathrm{X}$ & $\mathrm{X}$ & $\mathrm{X}$ & $\mathrm{X}$ & $\mathrm{X}$ & $\mathrm{X}$ & $\mathrm{X}$ & $\mathrm{X}$ & $\mathrm{X}$ & $\mathrm{X}$ & $\mathrm{X}$ & $\mathrm{X}$ \\
\hline $\begin{array}{l}\text { Independent } \\
\text { Variables }\end{array}$ & & & & & & & & & & & & & \\
\hline $\begin{array}{c}\text { GDP of } \\
\text { Turkey/GDP } \\
\text { of Greece }\end{array}$ & $\begin{array}{c}242.8392 \\
(0.290)\end{array}$ & & & & & & & & & & & & \\
\hline $\begin{array}{l}\text { GDP growth of } \\
\text { Turkey/GDP } \\
\text { growth of Greece }\end{array}$ & & $\begin{array}{c}-8.671979 \\
(-0.28)\end{array}$ & & & & & & & & & & & \\
\hline $\begin{array}{l}\text { GDP per capita } \\
\text { of Turkey/GDP } \\
\text { per capita } \\
\text { of Greece }\end{array}$ & & & $\begin{array}{c}1065.203 \\
(0.56)\end{array}$ & & & & & & & & & & \\
\hline $\begin{array}{c}\text { Total Reserves } \\
\text { of Turkey/Total } \\
\text { Reserves of Greece }\end{array}$ & & & & $\begin{array}{c}34.60163^{*} \\
(1.97)\end{array}$ & & & & & & & & & \\
\hline $\begin{array}{c}\text { Exports as a } \\
\text { percent of GDP of } \\
\text { Turkey/Exports } \\
\text { as a percent of } \\
\text { GDP of Greece }\end{array}$ & & & & & $\begin{array}{c}2233.314^{* * *} \\
(2.89)\end{array}$ & & & & & & & & \\
\hline $\begin{array}{l}\text { Balance of Trade } \\
\text { of Turkey/Balance } \\
\text { of Trade of Greece }\end{array}$ & & & & & & $\begin{array}{c}30.07679 \\
(0.28)\end{array}$ & & & & & & & \\
\hline $\begin{array}{c}\text { Defense } \\
\text { Expenditure of } \\
\text { Turkey/Defense } \\
\text { Expenditure of } \\
\text { Greece }\end{array}$ & & & & & & & $\begin{array}{c}291.7782 \\
(0.96)\end{array}$ & & & & & & \\
\hline $\begin{array}{l}\text { Debt as a percent } \\
\text { of GDP of } \\
\text { Turkey/Debt as } \\
\text { a percent of GDP } \\
\text { of Greece }\end{array}$ & & & & & & & & $\begin{array}{c}-294.8382 \\
(-0.10)\end{array}$ & & & & & \\
\hline $\begin{array}{c}\text { Unemployment } \\
\text { of Turkey/ } \\
\text { Unemployment } \\
\text { of Greece }\end{array}$ & & & & & & & & & $\begin{array}{c}547.7131 \\
(0.92)\end{array}$ & & & & \\
\hline $\begin{array}{l}\text { Market Cap as a } \\
\text { percent of GDP } \\
\text { of Turkey/Market } \\
\text { Cap as a percent } \\
\text { of GDP of Greece }\end{array}$ & & & & & & & & & & $\begin{array}{c}-556.4894 \\
(-1.54)\end{array}$ & & & \\
\hline $\begin{array}{l}\text { Market Cap of } \\
\text { Turkey/Market } \\
\text { Cap of Greece }\end{array}$ & & & & & & & & & & & $\begin{array}{c}-167.066 \\
(-1.52)\end{array}$ & & \\
\hline $\begin{array}{l}\text { FDI (Net Inflows) } \\
\text { as a percent of } \\
\text { GDP of } \\
\text { Turkey/FDI } \\
\text { (Net Inflows) as } \\
\text { a percent of GDP } \\
\text { of Greece }\end{array}$ & & & & & & & & & & & & $\begin{array}{c}-0.0275064 \\
(-0.03)\end{array}$ & \\
\hline
\end{tabular}




\section{Continued}

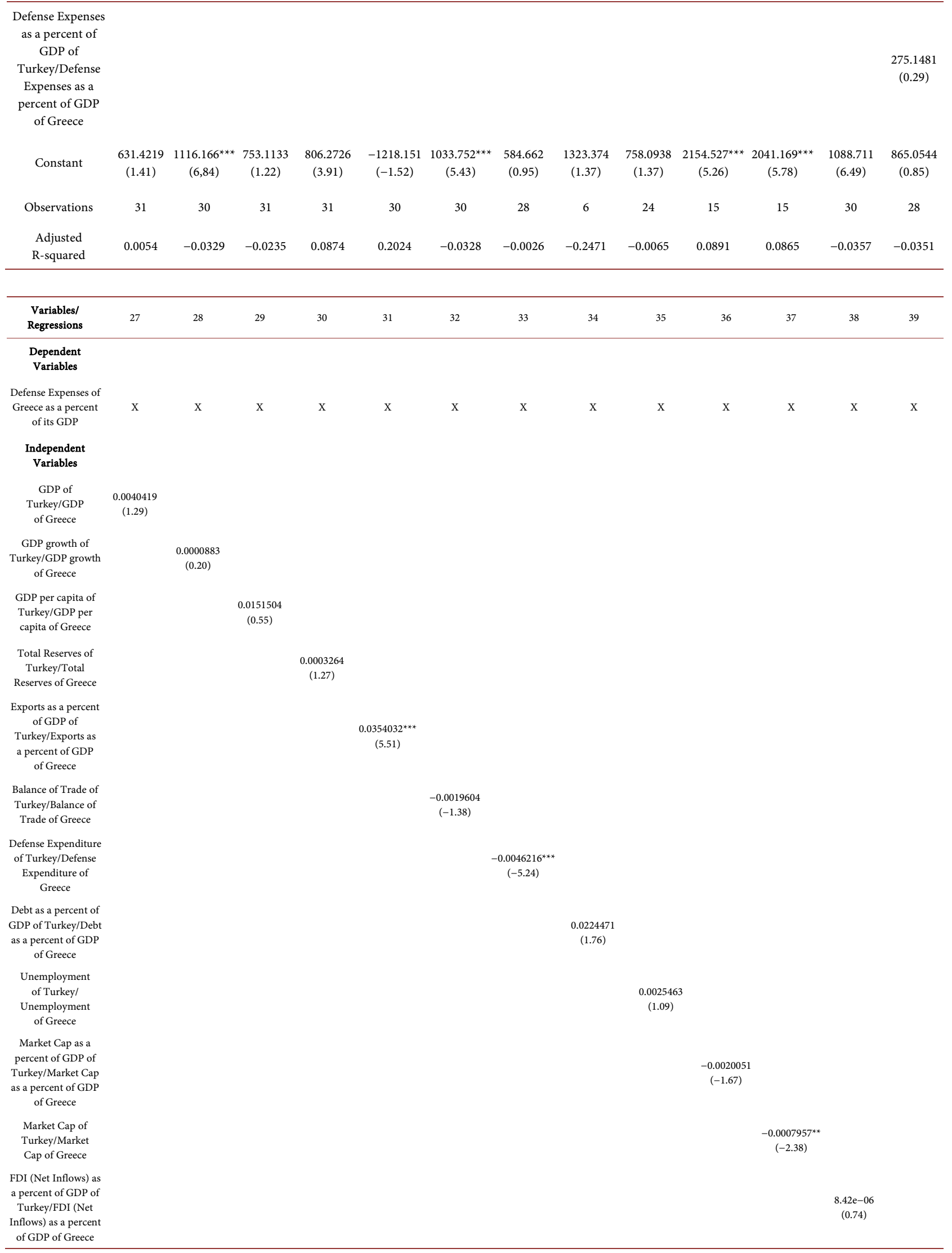




\section{Continued}

Defense Expenses as

a percent of GDP of

Turkey/Defense

Expenses as a percent

of GDP of Greece

Constant

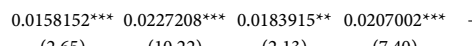

$\begin{array}{llll}(2.65) & (10.22) & (2.13) & (7.40)\end{array}$

Observations

36

Adjusted R-squared $\quad 0.0187$

35

$-0.0291$

$-0.0203$

Notes: $\mathrm{t}$-values in parenthesis; ${ }^{* *}$ statistically significant at the $1 \%$ level; ${ }^{* *}$ statistically significant at the $5 \%$ level; ${ }^{*}$ statistically significant at the $10 \%$ level. Regressions run by the authors with data taken from the following sources: Kollias, 2004, Hellenic Ministry of Foreign Affairs-Directorate A4: Turkey, 2015, 2009-2015: Hellenic National Defense General Staff, 2018, SIPRI, 2015, World Bank, 2015, UNcomtrade, 2015, UNCTAD, 2018, OECD, 2015(RED sources to be added) [37]-[46]. the beliefs of Realism.

We regressed the Total Number of Violations with the GDP of Turkey/GDP of Greece, the GDP growth of Turkey/GDP growth of Greece, the GDP per capita of Turkey/GDP per capita of Greece, the Total Reserves of Turkey/Total Reserves of Greece, the Exports as a percent of GDP of Turkey/Exports as a percent of GDP of Greece, the Balance of Trade of Turkey/Balance of Trade of Greece, the Defense Expenditure of Turkey/Defense Expenditure of Greece, the Debt as a percent of GDP of Turkey/Debt as a percent of GDP of Greece, the Unemployment of Turkey/Unemployment of Greece, the Market Cap as a percent of GDP of Turkey/Market Cap as a percent of GDP of Greece, the Market Cap of Turkey/Market Cap of Greece, the FDI (Net Inflows) as a percent of GDP of Turkey/FDI (Net Inflows) as a percent of GDP of Greece, and the Defense Expenses as a percent of GDP of Turkey/Defense Expenses as a percent of GDP of Greece, to find that it is positively correlated with the Total Reserves of Turkey/Total Reserves of Greece and the Exports as a percent of GDP of Turkey/ Exports as a percent of GDP of Greece at all significance levels and the GDP of Turkey/GDP of Greece at the 5\% significance level. It is negatively correlated at the $10 \%$ level with the Market Cap as a percent of GDP of Turkey/Market Cap as a percent of GDP of Greece. The rest of the variables show no statistical significance. This means that practically the increase of the relative strength of Turkey leads to an increase of the Total Number of Violations. The only exception is the market cap as a percent of GDP, which however increased the last 8 years (2007-2015) due potentially to the huge drop of the Greek market cap, primarily attributed to the extended economic crisis in the country.

We regressed the Violations of the Greek Airspace with all the independent variables individually to see that they are positively correlated at all levels with the Exports as a percent of GDP of Turkey/Exports as a percent of GDP of Greece and at the $10 \%$ level with the Total Reserves of Turkey/Total Reserves of Greece. The other variables exhibit no statistical significance. This implies that as the relative strength of Turkey increases then the Number of Violations of the Greek Airspace increase.

We regressed the Defense Expenses of Greece as a percent of its GDP with all 
the relative strength independent variables individually to see that they are positively correlated with the Exports as a percent of GDP of Turkey/Exports as a percent of GDP of Greece. They are negatively correlated with the Defense Expenses as a percent of GDP of Turkey/Defense Expenses as a percent of GDP of Greece at all significance levels and the Market Cap of Turkey/Market Cap of Greece at the 5\% significance level. The remaining of the variables posts no statistical significance. This also means that as the relative strength of Turkey increases the Defense Expenses of Greece as a percent of its GDO increase. The exception is the Defense Expenses as a percent of GDP of Turkey/Defense Expenses as a percent of GDP of Greece that is negatively correlated; however this can be explained by the fact that the Defense Expenses as a percent of GDP of Greece are at the denominator. We should possibly exclude this independent variable from our regressions. The other exception is the Market Cap of Turkey/Market Cap of Greece. As before we note that the Market Cap of Greece plunged during the last 8 years (2007-2015) of our dataset.

The above findings show that as the relative power of Turkey increases the measures of national security threat increase as well. Consequently, the increase of relative strength does not promote peace either. One would believe that the establishment of relative power would make the strengthened country more generous; however this is hardly the case. This is in line with the beliefs of Realism.

\section{Conclusion}

Regarding bilateral military relations, there are two points that should be mentioned. Firstly, Turkey is a greater power than Greece with regard to military capabilities. Keeping its Military Expenditure high, it remains one of the most significant powers in South-Eastern Europe and makes it difficult for Greece, to maintain a satisfactory level of deterrence, especially in the last five years during which the country has had to deal with financial and debt crisis. Secondly, given that both countries belong to the same military alliance without possessing any nuclear weapons, it is important as a matter of strategic thinking, especially bearing in mind Turkish threats and violations of Greek sovereignty, that the latter should not rest on its laurels and hope that joining the same alliance is enough to protect its national security. Last but not least, from 1974 onwards Turkey has continued to implement its revisionist plans becoming more aggressive, since it uses more than one military means at the same time in order to promote its interests and decrease Greece's geostrategic power and influence. Therefore, in light of the configuration of the conflict, bilateral relations between the two states have not improved nor has the sense of security increased for Greece since all indications received show that there is a serious ongoing national security threat from the other side. Last but not least, it is also noticeable that although military capabilities do not "solve" the problem, they can control conflict escalation to a high degree in addition to bilateral economic relations which do not affect the conflict. 


\section{Conflicts of Interest}

The authors declare no conflicts of interest regarding the publication of this paper.

\section{References}

[1] Grieco, J. (1988) Anarchy and the Limits of Cooperation: A Realist Critique of the Newest Liberal Institution. International Organization, 42, 485-507. https://doi.org/10.1017/S0020818300027715

[2] Gilpin, R. (1981) War and Change in World Politics. Cambridge University Press, New York. https://doi.org/10.1017/CBO9780511664267

[3] Mastanduno, M. (1998) Economics and Security in Statecraft and Scholarship. International Organization, 52, 825-854. https://doi.org/10.1162/002081898550761

[4] Dunne, T. (2008) Liberalism. In: Baylis, J., Smith, S. and Owens, P., Eds., The Globalization of World Politics, 4th Edition, Oxford University Press, Oxford, 108-123.

[5] Keohane, R. and Nye, J. (1972) Transnational Relations and World Politics. Harvard University Press, Cambridge, MA. https://doi.org/10.4159/harvard.9780674593152

[6] Keohane, R. and Nye, J. (2001) Power and Interdependence. 3rd Edition, United States of America, Longman.

[7] Long, A.G. (2008) Bilateral Trade in the Shadow of Armed Conflict. International Studies Quarterly, 52, 81-101. https://doi.org/10.1111/j.1468-2478.2007.00492.x

[8] Keohane, R. and Nye, J. (1977) Power and Interdependence: World Politics in Transition. Little Brown, Boston.

[9] Hirschman, Al., (1945) National Power and the Structure of Foreign Trade. University of California Press, Berkeley, Los Angeles, London.

[10] Krasner, S. (1978) Defending the National Interest: Raw Materials Investments and US Foreign Policy. Princeton University Press, Princeton.

[11] Gowa, J. and Mansfield, E.D. (1993) Power Politics and International Trade. American Political Science Review, 87, 408-420. https://doi.org/10.2307/2939050

[12] Oneal, J. and Russet, B. (1999) Assessing the Liberal Peace with Alternative Specifications: Trade Still Reduces Conflict. Journal of Peace Research, 36, 423-442. https://doi.org/10.1177/0022343399036004003

[13] Morrow, J. (1999) How Could Trade Affect Conflict? Journal of Peace Research, 36, 481-489. https://doi.org/10.1177/0022343399036004006

[14] Gartzke, E., Li, Q. and Boehmer, C. (2001) Investing in the Peace: Economic Interdependence and International Conflict. International Organization, 55, 391-438. https://doi.org/10.1162/00208180151140612

[15] Hegre, H. (2004) Development and the Liberal Peace: What Does It Take to Be a Trading State? Journal of Peace Research, 37, 5-30.

[16] Li, Q. and Sacko, D. (2002) The (Ir) Relevance of Militarized Interstate Disputes for International Trade. International Studies Quarterly, 46, 11-43. https://doi.org/10.1111/1468-2478.00221

[17] Long, A. and Leeds, B. (2006) Trading for Security: Military Alliances and Economic Agreements. Journal of Peace Research, 43, 433-451. https://doi.org/10.1177/0022343306065884

[18] Gelpi, C. and Grieco, J. (2008) Democracy Interdependence and the Sources of the 
Liberal Peace. Journal of Peace Research, 45, 17-36. https://doi.org/10.1177/0022343307084921

[19] Maoz, Z. (2009) The Effects of Strategic and Economic Interdependence on International Conflict across Levels of Analysis. American Journal of Political Science, 53, 223-240. https://doi.org/10.1111/j.1540-5907.2008.00367.x

[20] Herge, H., Oneal, J. and Russett, B. (2010) Trade Does Promote Peace: New Simultaneous Estimates of the Reciprocal Effects of Trade and Conflict. Journal of Peace Research, 47, 763-774. https://doi.org/10.1177/0022343310385995

[21] Li, Q. and Reuveny, R. (2011) Does Trade Prevent or Promote Interstate Conflict Initiation? Journal of Peace Research, 48, 437-453. https://doi.org/10.1177/0022343311406306

[22] Goldsmith, B. (2013) International Trade and the Onset and Escalation of Interstate Conflict: More to Fight about, or More Reasons Not to Fight? Defence and Peace Economics, 24, 555-578. https://doi.org/10.1080/10242694.2013.763637

[23] Copeland, D. (1996) Economic Interdependence and War: A Theory of Trade Expectations. International Security, 20, 5-41. https://doi.org/10.1162/isec.20.4.5

[24] Kapstein, Et. (2002) Two Dismal Sciences Are Better than One-Economics and the Study of National Security. International Security, 27, 158-187. https://doi.org/10.1162/01622880260553660

[25] Martin, Ph., Mayer, Th. and Thoenig, Mat. (2008) Make Trade Not War? Review of Economic Studies, 75, 865-900. https://doi.org/10.1111/j.1467-937X.2008.00492.x

[26] Barbieri, K. and Levy, J. (1999) Sleeping with the Enemy: The Impact of War on Trade. Journal of Peace Research, 36, 463-479. https://doi.org/10.1177/0022343399036004005

[27] Powers, K. (2004) Regional Trade Agreement as Military Alliances, International Interactions: Empirical and Theoretical Research. International Relations, 30, 373-395.

[28] Giallouridis, Ch. (2001) The Greek-Turkish Conflict: From Cyprus to Imia, the S300 and Helsinki 1955-2000. Athens, Sideris.

[29] Treaty of Lausanne (2018) Wiener Zeitung. https://www.wienerzeitung.at/_em_daten/_wzo/2015/03/13/150313_1621_1923_tre aty_of_lausanne.pdf

[30] Evagorou, Ev. (2010) The Greek-Turkish Relations from 1923 until Today. Vari, Poiotita.

[31] NATO (2018) NATO Member Countries. https://www.nato.int/cps/en/natohq/nato_countries.htm

[32] Turkish Ministry of Foreign Affairs (2018) Aegean Problems. http://www.mfa.gov.tr/sub.en.mfa?deb1dc4c-926f-45bd-9a7c-27b45654c0e4

[33] Hellenic Ministry of Foreign Affairs (2018) Issues of Greek-Turkish Relations. https://www.mfa.gr/en/issues-of-greek-turkish-relations

[34] Tsarouhas D. (2009) The Political Economy of Greek-Turkish Relations. Southeast European and Black Sea Studies, 9, 39-57. https://doi.org/10.1080/14683850902723397

[35] Roukanas, S. and Sklias, P. (2014) The Hellenic Political Economy 2000-2010: From the EMU to the Mechanism Support. Athens, Livani. (In Greek)

[36] Kotios, A. and Roukanas, S. (2013) The Greek Crisis and the Crisis in Eurozone's Governance. In: Sklias, P. and Tzifakis, N., Eds., Greece's Horizons. Reflecting on the Country's Assets and Capabilities, Springer, Athens, 91-105. 
https://doi.org/10.1007/978-3-642-34534-0_8

[37] World Bank (2017) World Bank Open Data. https://data.worldbank.org

[38] OECD (2017) OECD Data.

https://data.oecd.org/trade/trade-in-goods-and-services.htm

[39] Bilateral Trade 1974-2014 Greece to/from Turkey. https://comtrade.un.org/db/

[40] UNcomtrade (2015) Bilateral Trade.

http://comtrade.un.org/db/dqBasicQueryResults.aspx? $y=2014 \& \mathrm{rg}=1 \& \mathrm{p}=792 \& \mathrm{cc}=\mathrm{T}$ OTAL\&px $=\mathrm{S} 1 \& \mathrm{r}=300$

[41] (2018) Direction of Trade Statistics (DOTS).

https://data.world/imf/direction-of-trade-statistics-dots

[42] Hellenic Ministry of Foreign Affairs-Directorate A4: Turkey (2015).

[43] Hellenic National Defense General Staff (2018) Violations.

http://www.geetha.mil.gr/el/violations-gr.html

[44] Stockholm International Peace Research Institute (SIPRI) (2018) Military Spending and Armaments. http://www.sipri.org/research/armaments/milex/milex_database

[45] UNCTAD (2018) Bilateral FDI.

https://unctad.org/en/Pages/DIAE/FDI\%20Statistics/FDI-Statistics-Bilateral.aspx

[46] Kollias, Chr. (2004) The Greek-Turkish Rapprochement, the Underlying Military Tension and Greek Defense Spending. Turkish Studies, 5, 99-116.

https://doi.org/10.1080/14683849.2004.9687244 